\title{
PENGEMBANGAN MODEL PEMBELAJARAN "KOLABORATIF AKTIF (KA)" UNTUK MENINGKATKAN AKTIVITAS BELAJAR PELAJARAN MATEMATIKA PADA PESERTA DIDIK PROGRAM KEJAR PAKET C PKBM KI HAJAR DEWANTARA KECAMATAN NGRONGGOT KABUPATEN NGANJUK
}

\author{
Festian Cindarbumi ${ }^{1}$ \\ Universitas Nahdlatul Ulama Sunan Giri, festian.cindarbumi@ unugiri.ac.id $^{1}$ \\ Received : 28 Maret 2018, Accepted : 1 April 2018, ( Mathematics Education Unugiri 2018
}

\begin{abstract}
This paper discusses the development of collaborative learning models in modification by means of active learning, in this development to follow up P1, where in P1 there are still many weaknesses weakness after identification on its application, it is hoped that this P2 can cover all the weakness and can cover the deficiencies in every development, hope development that will be done so as to create a new model of learning and can be applied to learners on mathematics. Learning activities of learners are seen before and after the development of active collaborative learning model (KA). By increasing the learning activities of PKBM environmental learners in Cengkok Village, Ngronggot District Nganjuk Sub-Province, it can be useful to motivate and increase learning activities so that the learning achievement of Mathematics is conducive for students who are trying to get $C$ package.
\end{abstract}

Keywords: Development, Collaborative, Activity

\begin{abstract}
Abstrak
Makalah ini membahas tentang pengembangan model pembelajaran kolaboratif di modifikasi dengan dengan cara belajar aktif, dalam pengembangan ini untuk menindak lanjuti P1, dimana pada P1 masih banyak kelemahan kelemahan setelah dilakukan identifikasi pada penerapannya, dihaharapkan pada P2 ini dapat menutupi segala kelemaahan dan dapat menutupi kekurangan-kekurangan pada setiap pengembangan, harapan pengembangan yang akan di lakukan sehingga menciptakan suatu model pembelajaran yang baru dan dapat di terapkan pada peserta didik pada matapelajaran Matematika. Aktivitas belajar peserta didik dilihat sebelum dan sesudah dilaksanakan pengembangan model pembelajaran kolaboratif aktif (KA). Dengan meningkatkan aktivitas belajar peserta didik lingkungan PKBM di Desa Cengkok Kecamatan Ngronggot Kabupaten Nganjuk, dapat bermanfaat untuk memotivasi dan meningkatkan aktivitas belajar sehingga tercapai pembelajaran Matematika yang kondusif bagi peserta didik kejar paket C.
\end{abstract}

Kata kunci: Pengembangan, Kolaboratif, Aktivitas.

\section{Pendahuluan}

Perkembangan zaman yang semakin modern terutama pada era globalisasi seperti sekarang ini menuntut adanya sumber daya manusia yang berkualitas tinggi. Peningkatan kualitas sumber daya manusia merupakan syarat untuk mencapai tujuan pembangunan.
Salah satu upaya untuk meningkatkan sumber daya manusia tersebut adalah pendidikan.

Pendidikan merupakan aspek penting dalam kehidupan manusia. Kualitas sumber daya suatu bangsa sangat bergantung pada mutu pendidikan Negara tersebut. Kemajuan teknologi serta globalisasi yang kuat dan 
terbuka yang terjadi memberikan kesadaran baru bahwa Indonesia sebagai Negara yang sedang berkembang tidak lagi berdiri sendiri tetapi juga ditengah-tengah dunia yang baru, dunia terbuka sehingga orang bebas membandingkan kehidupan di Negara lain. Tetapi pada kenyataannya masyarakat Indonesia masih menghadapi masalah pendidikan yang berat terutama berkaitan dengan kualitas, relevansi, dan efisiensi. Dampak dari masalah tersebut terlihat dari sumber daya manusia Indonesia yang begitu rendah dalam hal kecakapan hidup (life skill) dan pengetahuan. Hal ini terbukti sebagai Negara yang sedang berkembang Indonesia dituntut untuk selalu mengembangkan pendidikan.

Peningkatan mutu pendidikan nasional di Indonesia terus-menerus diupayakan oleh pemerintah karena tujuan dari pendidikan nasional yang tertuang dalam UU Republik Indonesia Nomor 20 Tahun 2003 tentang Sistem Pendidikan Nasional [3] yang berbunyi : Pendidikan nasional berfungsi mengembangkan kemampuan dan membentuk watak serta peradaban bangsa yang bermartabat dalam rangka mencerdaskan kehidupan bangsa, bertujuan untuk berkembangnya potensi peserta didik agar menjadi manusia yang beriman bertaqwa kepada Tuhan Yang Maha Esa.

Banyak masyarakat yang putus sekolah dan tidak memiliki kemampuan pengetahuan yang memadai. Mereka memerlukan pengetahuan, keterampilan agar mudah memperoleh informasi tentang kesehatan, lingkungan, pendidikan, dunia kerja, dan yang terpenting untuk belajar sepanjang hayat mereka.

Keterampilan-keterampilan

ini dibutuhkan untuk pemberdayaan, supaya masyarakat bisa lebih langsung mengawasi kehidupan mereka, secara aktif berpartisipasi dalam masyarakat sebagai warga negara yang bertanggung jawab dan ikut berkontribusi, meningkatkan penghidupan mereka.

Mutu pendidikan rendah merupakan masalah besar dalam program pendidikan kesetaraan (Paket C). Antisipasi terhadap keterpurukan hasil belajar dicarikan solusi diantaranya melalui berbagai kegiatan seperti: pelatihan tutor, penerapan berbagai pedekatan/model pembelajaran diantaranya melalui pengembangan model pembelajaran. Dalam kondisi seperti ini dapat diyakini dengan melalui pengembangan suatu model pembelajran menjadi solusi yang terbaik untuk mangatasinya, karena Pengembangan model pembelajaran yang memungkinkan terjadi kerjasama yang baik antara tutor dan warga belajar, kegairahan belajar bisa tercipta sehingga pembelajaran lebih optimal dan hasil belajar dapat meningkat jauh.

Dengan adanya pengembangan model pembelajaran program kelompok belajar paket C setara SMA, ini kami berharap angka melanjutkan ke jenjang SMA meningkat dan juga tamatannya, juga kami berharap angka tidak melanjutkan/putus SMA di Kecamatan Ngronggot kami bisa turun, yang berakibat makin terpenuhi keinginan dari masyarakat dan pemerintah dalam mengentaskan program Wajar Dua Belas Tahun; dan lebih lagi akan mencerdaskan kehidupan bangsa dan negara. Terwadahinya keinginan masyarakat dalam menambah ilmu, khususnya untuk yang berada pada ekonomi yang sulit.

Salah satu alternatif lain yang dapat ditempuh melalui pengembangan model pembelajaran yang cocok dengan karakteristik warga belajar secara kontinu, dianggap strategis dalam upaya akselerasi peningkatan motivasi dan hasil belajar warga yaitu dengan melalui pengembangan model pembelajaran. Dimana dengan mengembangkan model ini diharapkan dapat bermanfaat untuk diimplementasikan dalam pembelajaran yang dilaksanakan dan mempunyai dampak terhadap peningkatan semangat belajar, sehingga tentunya memiliki dampak pula pada hasil belajar warga belajar turut meningkat.

Pengembangan model pembelajaran dapat memberdayakan peserta didik dalam meningkatkan semangat dan hasil belajarnya, mereka janganlah di pandang sebagai obyek tetapi sebagai subyek. 
2. Pembahasan

\section{a. Pengembangan 1.}

Salah satu strategi pembelajaran yang efektif ialah strategi kolaboratif karena dianggap Pembelajaran kolaboratif dapat menyediakan peluang untuk menuju pada kesuksesan praktek-praktek pembelajaran. Sebagai teknologi untuk pembelajaran (technology for instruction), pembelajaran kolaboratif melibatkan partisipasi aktif para peserta didik dan meminimisasi perbedaanperbedaan antar individu [2].

Daniel Muijs \& David Reynolds [1] menjelaskan bahwa strategi pembelajaran aktif merupakan cara pengajaran yang sangat interaktif, dan siswa diberi kesempatan untuk mengeksplorasi lingkungan. Hal inilah yang mendukungnya strategi kolaboratif dengan mengkobinasikan beberapa model-model pembelajaran yang mempunyai beberapa kelebihan.

Tabel 1. Model Pembelajaran Kolaboratif Kejar Paket C

\begin{tabular}{|c|c|c|}
\hline No & $\begin{array}{l}\text { Model tradisional/ } \\
\text { konvensional }\end{array}$ & Kolaboratif \\
\hline 1. & $\begin{array}{l}\text { berorientasi pada } \\
\text { teacher center } \\
\text { learning }\end{array}$ & $\begin{array}{l}\text { berorientasi pada } \\
\text { pembelajaran student } \\
\text { center learning }\end{array}$ \\
\hline 2. & $\begin{array}{l}\text { segala informasi } \\
\text { bersumber dari tutor, } \\
\text { peserta didik hanya } \\
\text { menerima apa yang } \\
\text { dijelaskan oleh tutor. }\end{array}$ & $\begin{array}{l}\text { pengetahuan di } \\
\text { konstruk, ditemukan, } \\
\text { dan di transformasikan } \\
\text { oleh peserta didik, } \\
\text { disini tutor berfungsi } \\
\text { sebagai fasilitator }\end{array}$ \\
\hline 3. & $\begin{array}{l}\text { tutor terfokus pada } \\
\text { bagaimana cara untuk } \\
\text { "mengajar" } \\
\text { sementara yang } \\
\text { terpenting itu adalah } \\
\text { bagaimana peserta } \\
\text { didik itu dapat } \\
\text { "belajar". }\end{array}$ & $\begin{array}{l}\text { usaha tutor bertujuan } \\
\text { pada mengembangkan } \\
\text { kompetensi dan talenta } \\
\text { peserta didik }\end{array}$ \\
\hline 4. & $\begin{array}{l}\text { pendidikan hanya } \\
\text { terfokus pada tutor } \\
\text { tanpa ada atau } \\
\text { jarangnya interaksi } \\
\text { peserta didik }\end{array}$ & $\begin{array}{l}\text { pendidikan merupakan } \\
\text { suatu transaksi } \\
\text { personal diantara } \\
\text { peserta didik bersama- } \\
\text { sama }\end{array}$ \\
\hline 5. & $\begin{array}{l}\text { motivasi belajar lebih } \\
\text { banyak datang dari } \\
\text { luar diri peserta didik. }\end{array}$ & $\begin{array}{l}\text { motivasi belajar banyak } \\
\text { bersumber pada diri } \\
\text { pendidik tersebut }\end{array}$ \\
\hline
\end{tabular}

Berikut ini langkah-langkah pembelajaran kolaboratif :

1) Para peserta didik dalam kelompok menetapkan tujuan belajar dan membagi tugas sendiri-sendiri.

2) Semua peserta didik dalam kelompok membaca, berdiskusi, dan menulis.

3) Belajar secara bersinergi mengidentifikasi, mendemontrasikan, meneliti, menganalisis, dan memformulasikan jawaban-jawaban tugas atau masalah dalam modul atau masalah yang ditemukan sendiri.

4) Setelah kelompok kolaboratif menyepakati hasil pemecahan masalah, masing-masing peserta didik menulis laporan sendiri-sendiri secara lengkap.

5) Tutor menunjuk salah satu kelompok secara acak (selanjutnya diupayakan agar semua kelompok dapat giliran ke depan) untuk melakukan presentasi hasil diskusi kelompok kolaboratifnya di depan kelas, peserta didik pada kelompok lain mengamati,mencermati, membandingkan hasil presentasi tersebut, dan menanggapi. Kegiatan ini dilakukan selama lebih kurang 20-30 menit.

6) Masing-masing peserta didik dalam kelompok kolaboratif melakukan elaborasi, inferensi, dan revisi (bila diperlukan) terhadap laporan yang akan dikumpulan.

7) Laporan masing-masing peserta didik terhadap tugas-tugas yang telah dikumpulkan, disusun perkelompok kolaboratif.

8) Laporan peserta didik dikoreksi, dikomentari, dinilai, dikembalikan pada pertemuan berikutnya, dan didiskusikan.

Model pembelajaran kolaboratif dalam operasionalnya dapat diidentifikasi melalui komponen-komponen perencanaan, pelaksanaan, dan evaluasi indikatorkurikulum/pembelajaran, bahan ajar, kelompok sasaran, nara sumber/tutor, metode dan media pembelajaran. Indikator tersebut merupaka komponen utama dalam pengembangkan model terigrasi dalam pembelajaran untuk 
meningkatkan hasil belajar perserta didik. Indikator-indikator tersebut diwujudkan dalam bentuk kompetisi: kognitif,afektif, pisikomotor.

\section{b. Evaluasi}

Dari hasil Identifikasi di lapangan masih ada ditemukannya masalah suatu pengembangan model pembelajaran kolaborasi tersebut di pengaruhi beberapa faktor sebagai berikut:

1) Usia peserta didik yang tidak sama

2) Tingkat Pengetahuan peserta didik yang tidak sama

3) Peserta didik yang memiliki kemampuan tinggi dan peserta didik yang memiliki kemampuan kurang, yang kemudian menimbulkan rasa tidak percaya diri bagi peserta didik yang kurang kemampuannya

4) Membutuhkan waktu cukup banyak.

5) Kebulatan atau kesimpulan bahan kadang sukar dicapai.

6) Bahwa persiapan tutor menjadi lebih lama dan lebih serius.

7) Aktivitas tutor dalam pembelajaran menjadi lebih padat.

Tabel 2. Model Pembelajaran Kolaboratif Kejar Paket C Pengembangan 1

\begin{tabular}{|l|l|}
\hline \multicolumn{1}{|c|}{ Kelebihan } & \multicolumn{1}{|c|}{ kelemahan } \\
1. Peserta didik & 1. Ada kemungkinan bagi \\
bermusyawarah & $\begin{array}{l}\text { peserta didik tertentu } \\
\text { aktivitasnya menjadi asal- } \\
\text { 2. Peserta didik } \\
\text { belajar }\end{array}$ \\
menghargai & dengan mudah \\
pendapat orang & mengandalkan teman atau \\
lain & 2. Bagi tutor, yang harus \\
3. Dapat & dihindari adalah \\
mengembangkan & kecenderungan \\
cara berpikir & memberikan tugas yang \\
kritis dan & berlebih kepada peserta \\
rasional & didik. \\
4. Dapat memupuk & 3. Adanya sifat-sifat pribadi \\
rasa kerja sama & yang ingin menonjolkan \\
5. Adanya & diri atau sebaliknya yang \\
persaingan yang & lemah merasa rendah diri \\
sehat & dan selalu tergantung \\
& pada orang lain. \\
\hline
\end{tabular}

\begin{tabular}{|l|l|}
\hline Kelebihan & \multicolumn{1}{|c|}{ kelemahan } \\
\hline & $\begin{array}{l}\text { 4.Pendapat serta pertanyaan } \\
\text { peserta didik dapat } \\
\text { menyimpang dari pokok } \\
\text { persoalan. }\end{array}$ \\
\hline
\end{tabular}

Menanggapi hal tersebut maka model pembelajaran kolaborasi perlu dikembangkan lagi agar tujuan pembelajaran yang aktif dan efektif dapat berjalan sesuai yang di harapkan maka model pembelajaran kolaboratif ini perlu di kembangakan lagi untuk mencapai tujuan program pembelajaran kejar paket $\mathrm{C}$, karena masih banyak mempunyai kelemahankelemahan yang harus di minimalisir dalam proses pembelajaran.

\section{c. Pengembangan 2}

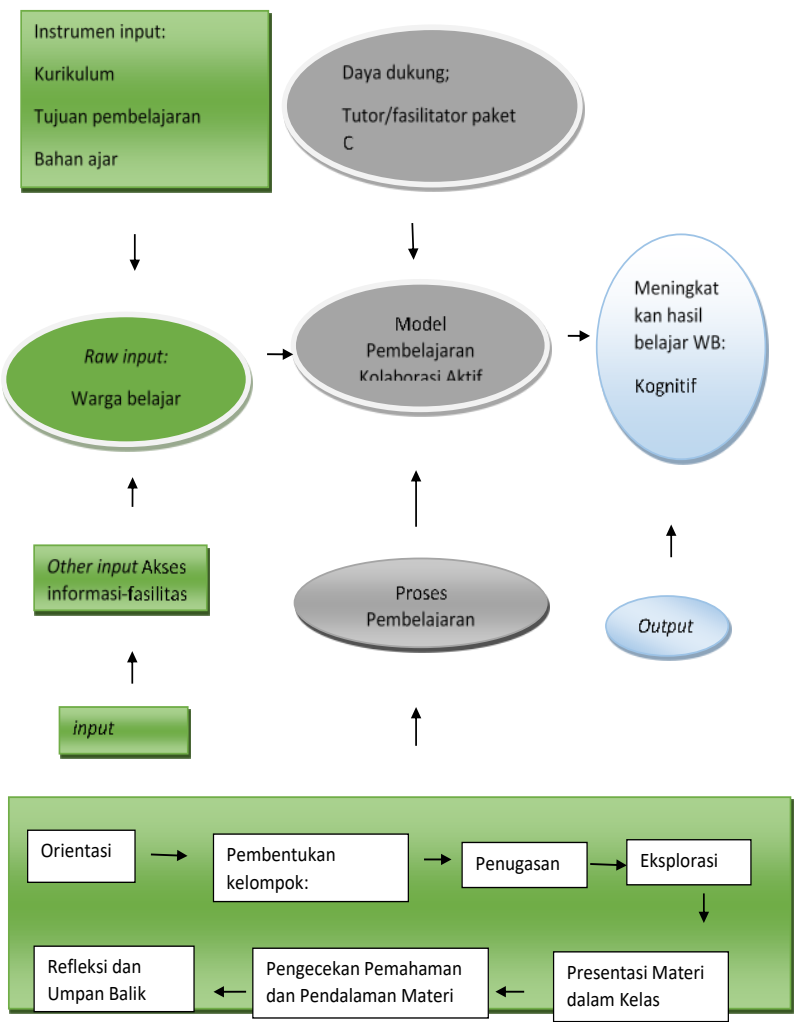

Gambar 1. Kerangka Pemikiran Model Pembelajaran Pengembangan KA

Dalam P2 ini untuk menindak lanjuti P1, dimana pada P1 masih banyak kelemahan kelemahan setelah dilakukan identifikasi pada penerapannya, dihaharapkan pada P2 ini dapat menutupi segala kelemaahan dan dapat menutupi kekurangan-kekurangan pada setiap 
pengembangan, harapan pengembangan yang akan di lakukan.

Adapun Alternatif prosedur pembelajaran KA untuk meningkatkan keaktifan peserta didik dalam proses pembelajaran di kelas dapat dikembangkan ke dalam 8 tahap, seperti pada Gambar 1 .

Prosedur pembelajaran KA untuk meningkatkan keaktifan peserta didik dalam proses pembelajaran di kelas dikembangkan ke dalam 8 tahap, sebagai berikut:

1) Orientasi: Tutor mendeskripsikan ruang lingkup materi, mengemukakan tujuan, menyampaikan prosedur pembelajaran, dan menyampaikan alternatif bahan sumber belajar.

2) Pembentukan kelompok: Tutor mengidentifikasi karakteristik peserta didik, menetapkan jumlah kelompok dan jumlah anggotanya, serta menetapkan dan menginformasikan keanggotaan kelompok.

3) Penugasan: Tutor menyampaikan kisi-kisi materi dan memberikan tugas (pertanyaan) sesuai dengan topik dan indikator kompetensi yang harus dikuasai peserta didik; menugaskan setiap kelompok peserta didik untuk mendiskusikan, mencari sumber guna menyelesaikan tugas (pertanyaan) yang diberikan sesuai dengan topik yang dibahas masing-masing kelompok dan menyusunnya dalam bentuk bahan presentasi.

4) Eksplorasi: Peserta didik bersama kelompoknya mencari bahan sumber, mendiskusikan dan menyelesaikan setiap tugas yang diberikan, mendukung dan membantu teman yang mengalami kesulitan.

5) Presentasi Materi dalam Kelas: satu orang yang mewakili kelompok untuk presentasi, presentasi materi kelompok, tutor menanyakan kepada seluruh peserta didik tentang kejelasan inti materi yang telah dipresentasikan, memberi kesempatan pada anggota lain dari kelompok penyaji untuk memperjelas penyajian materi.

6) Pengecekan Pemahaman dan Pendalaman Materi: Memonitor tingkat pemahaman peserta didikterhadap materi, memberi kesempatan setiap peserta didik untuk berpendapat atau bertanya kepada kelompok penyaji.

7) Refleksi dan Umpan Balik: Tutor menjelaskan kembali beberapa pertanyaan yang belum terjawab dengan benar dan jelas oleh kelompok penyaji, memberikan rangkuman materi untuk mempertegas pemahaman peserta didik, memberi kesempatan setiap peserta didik untuk bertanya, menjawab dan menanggapi pertanyaan peserta didik.

\section{d. Hasil Pengembangan}

Pengembangan model pembelajaran "Kolaboratif Aktif (KA)" untuk meningkatkan hasil belajar peserta didik pada Pelajaran Matematika program kejar paket C PKBM Ki Hajar Dewantara Ngronggot Kabupaten Nganjuk bertujuan untuk mencari alternative dalam meningkatkan mutu penyelenggaraan program, pembelajaran, dan pembimbingan pada PNF, sementara fungsi pengembangan model diantaranya adalah untuk mempermudah pengertian, mempermudah komunikasi, mempermudah pemecahan masalah, dan mempermudah prediksi.

Tabel 3. Dimensi Pengembangan Model Pembelajaran Kolaboratif Aktif (KA)

\begin{tabular}{|l|l|l|l|}
\hline No. & \multicolumn{1}{|c|}{$\begin{array}{c}\text { Model } \\
\text { tradisional/konvensional }\end{array}$} & \multicolumn{1}{|c|}{ P1 } & \multicolumn{1}{c|}{ P2 } \\
\hline 1 & $\begin{array}{l}\text { berorientasi pada teacher } \\
\text { center learning }\end{array}$ & $\begin{array}{l}\text { berorientasi pada pembelajaran } \\
\text { student center learning }\end{array}$ & $\begin{array}{l}\text { berorientasi pada teacher center } \\
\text { learningdan student center } \\
\text { learning }\end{array}$ \\
\hline 2 & $\begin{array}{l}\text { segala informasi bersumber } \\
\text { dari tutor, peserta didik hanya } \\
\text { menerima apa yang dijelaskan } \\
\text { oleh tutor. }\end{array}$ & $\begin{array}{l}\text { pengetahuan di konstruk, } \\
\text { ditemukan, dan di } \\
\text { transformasikan oleh peserta } \\
\text { didik, disini tutor berfungsi } \\
\text { sebagai fasilitator }\end{array}$ & $\begin{array}{l}\text { Informasi bersumber dari tutor } \\
\text { dan peserta didik, peran tutor } \\
\text { sebagai sumber inforamasi dan } \\
\text { sebagai fasilitator }\end{array}$ \\
\hline 3 & $\begin{array}{l}\text { Tutor terfokus pada bagaimana } \\
\text { cara untuk "mengajar" } \\
\text { sementara yang terpenting itu } \\
\text { adalah bagaimana peserta didik } \\
\text { itu dapat "belajar". }\end{array}$ & $\begin{array}{l}\text { usaha tutor bertujuan pada } \\
\text { mengembangkan kompetensi dan } \\
\text { talenta peserta didik }\end{array}$ & $\begin{array}{l}\text { Mengembangkan kompetensi } \\
\text { peserta didik }\end{array}$ \\
\hline 4 & $\begin{array}{l}\text { pendidikan hanya terfokus } \\
\text { pada tutor tanpa ada atau } \\
\text { jarangnya interaksi peserta } \\
\text { didik }\end{array}$ & $\begin{array}{l}\text { pendidikan merupakan suatu } \\
\text { transaksi personal diantara } \\
\text { peserta didik bersama-sama }\end{array}$ & $\begin{array}{l}\text { Interaksi antara tutor dengan } \\
\text { peserta didik, interaksi antara } \\
\text { peserta didik dengan peserta } \\
\text { didik }\end{array}$ \\
\hline 5 & $\begin{array}{l}\text { motivasi belajar lebih banyak } \\
\text { datang dari luar diri peserta } \\
\text { didik. }\end{array}$ & $\begin{array}{l}\text { motivasi belajar banyak } \\
\text { bersumber pada diri pendidik } \\
\text { tersebut }\end{array}$ & Motivasi internal dan eksternal \\
\hline
\end{tabular}

Dari pengembangan 2 (P2) adalah untuk menjawab semua kelemahan-kelemahan model pembelajaran sebelumnya, antara lain dengan tujuan: 
a) Meningkatkan belajar peserta didik dan prestasi akademik peserta didik

b) Menambah perhatian peserta didik

c) Menambah kepuasan peserta didik dengan pengalaman belajar mereka.

d) Membantu peserta didik mengembangkan kemampuan dalam berkomunikasi.

e) Mengembangkan kemampuan bersosial peserta didik.

f) Meningkatkan peghargaan/harga diri peserta didik.

g) Membantu meningkatkan hubungan yang positif.

Menyadari kenyataan seperti ini berupaya untuk mencari dan merumuskan strategi yang dapat merangkul semua perbedaan yang dimiliki oleh anak didik. Strategi pembelajaran yang ditawarkan adalah strategi belajar KOLABORATIF AKTIF (KA).

Analisis aktivitas peserta didik dilakukan pada lembar penilaian afektif peserta didik selama berlangsungnya kegiatan belajar mengajar dengan model pembelajaran Kolaboratif aktif (KA). Peserta didik dinilai oleh pengamat dengan ketentuan sebagai berikut :

1. Kurang baik $=0,00-1,00$

2. Cukup baik $=1,01-2,00$

3. Baik $=2,01-3,00$

4. Sangat baik $=3,01-4,00$

Pada tabel 4 dapat diketahui bahwa aktivitas peserta didik secara keseluruhan pada pengembangan 2 memperoleh nilai rata-rata 2,9 dengan kategori baik. Aspek yang paling menonjol mendapatkan nilai 3,5 dengan kategori sangat baik yaitu peserta didik mendengarkan informasi dari tutor, berdiskusi dengan teman, mengerjakan lembar kerja, bertanya kepada teman atau tutor. Aspek yang lain yang mendapat nilai 3 adalah membaca menganalisis soal cerita dalam pelajaran matematika. Sedangkan Aspek yang lain mendapat nilai 2 dengan kategori cukup baik yaitu mengajukan pendapat. Pada saat kegiatan belajar mengajar juga masih ditemukan perilaku yang tidak relevan.
Tabel 4. Data Hasil Pengamatan Aktivitas Peserta didik Pelajaran Matematika



( Sumber : Data hasil pengamatan )

\section{Penutup}

Hasil dari hasil pengembangan model pembelajaran kolaboratif aktif (KA) yaitu membentuk karakteristik aktivitas belajar Matematika peserta didik di Lingkungan Sekolah Kejar Paket C dalam proses belajar. Peserta didik juga memerlukan karakteristik belajar matematika untuk meraih prestasi akademis. Untuk itu, karakteristik pembelajaran dibutuhkan dalam proses belajar untuk meraih prestasi, karena prestasi adalah kesuksesan peserta didik dalam menuntut ilmu di sekolah dan tutor adalah pembimbing. Kolaboratif Aktik (KA) dimaksudkan untuk mengoptimalkan penggunaan semua potensi yang dimiliki oleh peserta didik, disini peserta didik dituntut untuk mengunakan otak dalam berfikir sehingga semua peserta didik dapat mencapai hasil belajar yang memuaskan sesuai dengan karakteristik pribadi yang mereka miliki. Disamping itu pembelajaran Kolaboratif Aktik (KA) juga dimaksudkan untuk menjaga perhatian peserta didik agar tetap tertuju pada proses pembelajaran.

\section{Referensi}

[1] Daniel Muijs \& David Reynolds. Effective Teaching Teori dan Aplikasi, Yogyakarta: Pustaka Pelajar (2008).

[2] Kurniawan, Budi. Diambil dari https://kurniawanbudi04.wordpress.com/2 013/05/27/collaborative-learning/ (2013) pada tanggal 25 Maret 2018.

[3] Undang-Undang SISDIKNAS no.20 Tahun 2003. Sistem Pendidikan Nasional. Bandung: Fokus Media (2008). 